\title{
Total and permanganate-oxidizable organic carbon in the corn rooting zone of US Coastal Plain soils as affected by forage radish
}

cover crops and $\mathbf{N}$ fertilizer

Fang Wang abc,*, Ray R. Weil ${ }^{\mathrm{c}}$, Xiongxiong Nan ${ }^{\mathrm{d}}$

${ }^{a}$ College of Resources and Environmental Science, Ningxia University, Yinchuan, Ningxia 750021, China

${ }^{b}$ Institute of Environmental Engineering, Ningxia University, Yinchuan, Ningxia 750021, China

${ }^{c}$ Department of Environmental Science and Technology, University of Maryland, College park, MD 20742, USA

${ }^{d}$ Ningxia Forestry Institute Co., Ltd, Yinchuan, Ningxia 750004, China

\section{ABSTRACT}

Forage radish (Raphanus sativus L. var. longipinnatus) is a relatively new winter cover crop becoming widely grown in humid temperate North America. Little is known about how the use of this fall/winter cover crop may influence carbon sequestration and distribution in the soil profile in corn silage production system. The objectives of this study were to determine quantities and distribution in the soil profile of total organic carbon (TOC) and permanganate oxidizable carbon (POXC) as affected by forage radish cover crops and to examine the relationship between TOC and POXC in the profile. While there was no significant difference in TOC between radish (RAD) and no cover crop (NC) treatments for each depth interval at each site, the TOC in RAD $(10.3 \mathrm{~g} \mathrm{C} / \mathrm{kg})$ was higher compared with $\mathrm{NC}(9.3 \mathrm{~g} \mathrm{C} / \mathrm{kg})$ in surface soil depth $(0-30 \mathrm{~cm})$ when analyzed across all site years. Forage radish impacts on POXC were observed not only for surface horizons $(0-15 \mathrm{~cm})$, but also for deep horizons $(90-105 \mathrm{~cm})$. Banded nitrogen fertilizer affected the soil C:N ratio deep in the soil profile at both sites (at $90-105 \mathrm{~cm}$ in RAD and at $60-75 \mathrm{~cm}$ in $\mathrm{NC}$ ). Where 
$\mathrm{N}$ fertilizer was applied, soil POXC in $0-30 \mathrm{~cm}$ was significantly greater following radish $(535.7 \mathrm{mg} \mathrm{POXC} / \mathrm{kg}$ ) than following no cover crop (418.2 $\mathrm{mg} \mathrm{POXC} / \mathrm{kg}$ ). Additionally, strong positive linear relationships between POXC and TOC were observed $(P<0.05)$, with a much steeper regression slope (higher POXC/TOC ratio) in the $60-105 \mathrm{~cm}$ layer $(\mathrm{POXC} / \mathrm{TOC}$ ratio $=0.22)$ was much steeper than for the surface soil $(0-30 \mathrm{~cm})$ with $\mathrm{POXC} / \mathrm{TOC}$ ratio $=0.05$. We speculate that the higher POXC levels may have resulted from increased rooting and exudation by both corn and radish where nitrogen fertilizer was placed. Using forage radish cover crops show potential for mitigating against soil $\mathrm{C}$ depletion.

Keywords: Forage radish; Subsoil; Carbon; Permanganate oxidizable carbon; Distribution.

\section{Introduction}

Soil organic matter (SOM) is a key factor of soil quality since it influences nutrient holding and cycling, soil structure, erosion resistance, and soil biological processes (Weil and Magdoff, 2004; Lucas and Weil, 2012). Levels of SOM are most often estimated by measuring total organic carbon (SOC). Because SOC is such a large pool of $\mathrm{C}$ and mainly comprised of relatively stable material protected from decomposition, the effects of contrasting soil management practices may take many years to become apparent in SOC measurements (Weil et al., 2003). It remains difficult to measure small quantitative changes in SOC pools caused by variations in soil management practices over short time scales of a few years, despite the fact that these changes may impose significant effects on soil properties and associated 
microbial processes (Weil et al., 2003). Alternatively, labile soil organic carbon (LOC) is a relatively small fraction of TOC that has a short half life in soils and responds quickly to changes in soil management and fertilization practices (Weil and Magdoff, 2004). The LOC fraction is an important component that determines soil quality because of its involvement in soil aggregate stabilization (Tisdall and Oades, 1982) and its direct link to soil carbon $(\mathrm{C})$ and nitrogen $(\mathrm{N})$ mineralization (Gunapala and Scow, 1998).

Recently Culman et al. (2012), in a meta-analysis of 12 studies, presented evidence that the LOC reactive with a dilute $(0.02 \mathrm{M})$ potassium permanganate solution (Weil et al., 2003) is a microbial processed pool of labile soil C that often exhibits greater sensitivity to changes in management or environmental variation than other commonly measured parameters such as particulate organic carbon (POC), microbial biomass carbon (MBC) or total TOC. They recommended that this fraction be termed permanganate oxidizable carbon (POXC). Several recent studies have reported that POXC was one of the most sensitive and reliable indicators for evaluating the short- and long-term impacts of soil management practices on soil quality (Awale et al., 2013; Chen et al., 2009; DuPont et al., 2010; Melero et al., 2009; Morrow et al., 2016; Plaza-Bonilla et al., 2014; Spargo et al., 2011; Veum et al., 2014). Studies found that POXC quantified by a modified potassium permanganate method (Weil et al., 2003) is sensitive to the changes in SOC content induced by organic amendments (Miles and Brown, 2011), cover crop treatments (Jokela et al., 2009), and high-residue cropping systems (Miles and Brown, 2011). Lucas and Weil 
(2012) reported that POXC determination is useful for identifying soils where improved SOC management is likely to increase grain productivity and further contribute to soil quality interpretations for producers. Measurement of the POXC content of a soil is also a very simple, inexpensive and non-hazardous method for estimating the LOC fraction (Culman et al., 2012; Morrow et al., 2016; Lucas and Weil, 2012).

Forage radish (Raphanussativus L.) is a unique fall/winter cover crop that is relatively new but becoming rapidly adopted in temperate, humid North America. Forage radish performs a number of unique and desirable functions, including alleviating soil compaction through effective bio-drilling (Chen and Weil, 2010), and efficient capture of $\mathrm{N}$ from deep soil layers. The $\mathrm{N}$ capture function prevents excess $\mathrm{N}$ from leaching into natural waters (Kristensen and Thorup-Kristensen, 2004; Dean and Weil, 2009). The radish has also been reported to increase soil test phosphorous (White et al., 2011) and very effectively suppress early spring weeds (Lawley et al., 2011).

Given two months of favorable growing conditions in fall (600+ growing degree days), radish cover crops typically produce 3 to 8 metric tons/ha of dry matter (approximately $20-30 \%$ of which is in the fleshy, partially above ground root). Because of its rapid growth in fall, a forage radish cover crop can add significant quantities of organic carbon to the soil (Mutegi et al., 2011; Mutegi et al., 2013; Dean and Weil, 2009). It is important to keep in mind however that forage radish biomass is highly decomposable so the carbon added to the soil system after radish cover crops 
has a rapid turnover rate (Kremen and Weil, 2006). More sensitive measures of SOC (e.g., POXC) may be able to detect changes in SOC resulting from radish cover cropping but we could find no published studies to date investigating radish effects on labile soil organic carbon. Moreover, the vast majority of studies measuring cover crop and management effects on SOC have investigated only the upper 10 to $30 \mathrm{~cm}$ of soil, but the few studies that have looked deeper point to the importance of carbon changes in the deep subsoil layers (Baker et al., 2007; Jandl et al., 2014).

This study investigates corn silage production with and without the use of forage radish as a fall/winter cover crop planted immediately after corn is harvested for silage. Within each cover crop treatment (radish or no cover), low and high fertilizer application was also compared. The variables measured included above ground plant $\mathrm{C}$ and dry matter production and the distribution of TOC, C:N ratio and POXC in the upper $105 \mathrm{~cm}$ of the soil profile. Thus, the objectives of this study were (1) to evaluate the effect of forage radish on soil organic carbon distribution in profile, (2) to determine effects of radish cover cropping on POXC in the soil profile, (3) to measure the effect of band-applied V5 stage corn side-dress nitrogen solution on the soil TOC and POXC in the soil profile, and (4) to determine the relationship between the soil organic carbon and permanganate oxidizable carbon at different soil depths.

\section{Materials and Methods}

\subsection{Field site description and experimental design}

The study was conducted on two fields of the USDA Dairy Farm $\left(39^{\circ} 01^{\prime} \mathrm{N}\right.$, 7689' W) at Beltsville Agriculture Research Center, Beltsville, Maryland. A 
completely randomized split-plot design experiment with four replicates was conducted in field BARC1-18 from May 2011 through August 2012 and in field BARC1-21 from May 2012 through August 2013.

The dominant soils types at BARC1-18 are Christiana soils (Fine, kaolinitic, mesic Aquic Hapludults) with silt loam A horizons and clay loam Bt and C horizons. The BARC1-21 site is approximately $1 \mathrm{~km}$ away from BARC1-18, the soil is a complex of Russett soil (Fine-loamy, mixed, semi-active, mesic Aquic Hapludults) with silt loam A horizons mainly in Blocks 3 and 4 and Christiana soils mainly in Blocks 1 and 2. The general soil properties of the Ap horizon $(0-20 \mathrm{~cm})$ and the management histories (for the study period and the previous 3 years) of two fields are presented in Tables 1 and 2, respectively. Figure 1 shows the monthly mean air temperature and cumulative rainfall values for the sites during the study period.

During this study, no-till management was used in all fields. Sites BARC1-18 and 1-21 were divided into four blocks in May 2011 and 2012 respectively. Each block contained two main plots each randomly assigned one of two winter cover crop treatments: forage radish cover crop and no cover crop (crop residue and winter weeds only) (Fig. 2). The block dimension was $9.5 \mathrm{~m} \times 110 \mathrm{~m}$. The main plot size was $4.6 \mathrm{~m} \times 110 \mathrm{~m}$. In mid-June preceding the cover crop planting, $112 \mathrm{~kg} \mathrm{~N} \mathrm{ha}^{-1}$ as urea ammonium nitrate (UAN) solution was side-dressed in every other corn row middle in bands of liquid fertilizer applied $150 \mathrm{~cm}$ apart such that that each row of corn had access to nearby $\mathrm{N}$ on one side or the other, but not both sides. This allowed us to track this fertilizer $\mathrm{N}$ by differential growth and $\mathrm{N}$ uptake over the side-dress 
bands by cover crop plants drilled in rows just $15 \mathrm{~cm}$ apart. The $\mathrm{N}$ side-dressed and non-sidedressed strips were considered to be sub-plots characterized as high $\mathrm{N}$ (side-dressed row) and low N (non- side-dressed row) (Fig. 2). The sub plot size was $0.75 \mathrm{~m} \times 110 \mathrm{~m}$. In order to determine the effects of different $\mathrm{N}$ fertilizer rates on silage corn yield and examine whether corn silage, with or without a radish cover crop, benefits from side-dressed nitrogen fertilizer on these periodically manured soils, four $\mathrm{N}$ fertilization rates (no nitrogen, N0; $56 \mathrm{~kg} \mathrm{ha}^{-1}, \mathrm{~N} 1 ; 112 \mathrm{~kg} \mathrm{ha}^{-1}, \mathrm{~N} 2$; and $168 \mathrm{~kg} \mathrm{ha}^{-1}$, N3) were applied in June 2012 (BARC1-18) and 2013 (BARC1-21). These N rates were factorially combined with previous fall cover crop treatment as sub-subplots in a split-split plot design with four replications giving a total of 32 sub plots of $20 \mathrm{~m}$ length and $4.6 \mathrm{~m}$ width each.

The soil at BARC1-18 was cropped in a no-till soybean/cereal rye cover crop/corn rotation prior to this study (Table 2). During this experiment, a silage corn/radishes cover crop/silage corn rotation was used. No-till management was also practiced at BARC 1-11 for this experiment and during the previous $4 \mathrm{yr}$ with a corn/barley/soybean or corn/wheat/soybean rotation (Table 2). After corn silage harvest in mid-August of each year, $47000 \mathrm{~L} \mathrm{ha}^{-1}$ dairy cow manure slurry was spread and turbo tilled (Houle model, 5300) into the upper $5 \mathrm{~cm}$ of soil. In mid to late August, forage radish (Cover Crop Solutions) was no-till drilled (John Deere, 1590; $9 \mathrm{~kg}$ seed $\mathrm{ha}^{-1}$ ) into silage corn stubble for cover crop plots $100 \mathrm{~m}$ long in BARC 1-18 and 110 $\mathrm{m}$ long in BARC1-21 by $4.6 \mathrm{~m}$ wide. A same sized plot on one side or the other (randomly chosen) was not planted to a cover crop and designated the control plot. 
Forage radishes grew rapidly in fall and early winter until they were freeze-killed beginning in December or January. In May the field was again planted to silage corn (Pioneer, 34B62) with no planting time fertilizer. At side-dress time in June (V5 stage of corn growth), the previous fall cover crop plots were sub-divided into $\mathrm{N}$ rate plots as described above. Whole corn plants were harvested (CLAAS, JAGUAR 940) for silage in mid to late August.

\subsection{Field sampling}

\subsubsection{Plants}

Cover crop plants were taken from random locations at least $1 \mathrm{~m}$ from the ends of the plot. Plants were collected by block in January of 2011 and December of 2013 (Fig. 3). Two $0.25 \mathrm{~m}^{2}$ quadrats (centered in the high $\mathrm{N}$ side-dress or low $\mathrm{N}$ no side-dress subplot) of plant material (radishes in cover treatment and weeds in no cover treatment) were harvested in each subplot, and the dry weight of these samples was determined after drying. Subsamples were removed for analysis of carbon contents. Plant shoots were harvested for all treatments. For the forage radish, the large fleshy tap-roots, but not the fine roots, were sampled to approximately $15 \mathrm{~cm}$ depth by pulling up the whole plant, separating the fleshy root from shoot material and washing the roots free of soil. After collection, plants were dried at $65^{\circ} \mathrm{C}$ and ground to pass a 1-mm sieve. Plant dry matter measurements were used in conjunction with $\mathrm{C}$ analysis to determine plant $\mathrm{C}$ content:

$\mathrm{C}$ content $\left(\mathrm{kg} \mathrm{ha}^{-1}\right)=\mathrm{DM}^{*} \mathrm{C}$ where DM is plant dry matter $\left(\mathrm{kg} \mathrm{ha}^{-1}\right)$, and $\mathrm{C}$ is total $\mathrm{C}$ concentration $\left(\mathrm{kg} \mathrm{kg}^{-1}\right)$. 


\subsubsection{Soils}

Soil was sampled to $105 \mathrm{~cm}$ depth where allowed by site conditions and equipment capabilities using Giddings hydraulic probe. The soil cores were $3.81 \mathrm{~cm}$ in diameter. Cores were placed in 4-cm-diameter PVC troughs for examination and divided into $15-\mathrm{cm}$ sections. Six soil cores were taken in each cover crop plot. With respect to the rows of corn plant stubble, three cores were taken in the side-dress middle (high-N, subplot) and three in non-side dress middle (low-N subplot). The three cores were homogenized within the subplot to represent the particular depth increment and subplot. Soil sampling dates are given in Figure 3.

\subsection{Laboratory Analyses}

After collection, the wet weight of total soil was determined in lab. Then subsamples $(\sim 15 \mathrm{~g})$ were dried at $105{ }^{\circ} \mathrm{C}$ for gravimetric soil moisture determination. The remaining soil in each sample was immediately force-air dried at $55^{\circ} \mathrm{C}$ for 24 hours and passed through a $1 \mathrm{~mm}$ sieve for other analysis. Soil bulk density was calculated for each $15 \mathrm{~cm}$ depth increment.

Soil and plant total nitrogen and carbon was analyzed by the dry combustion method at $900^{\circ} \mathrm{C}$ using a $\mathrm{C}$ elemental analyzer (CHN 2000; LECO, St. Joseph, MI) for samples (ground to pass $0.25 \mathrm{~mm}$ sieve). Permanganate oxidizable carbon in soil was estimated by reaction with dilute permanganate solution (Weil et al., 2003). Briefly, portions $(2.5 \mathrm{~g})$ of air-dried soil were dispersed in $20 \mathrm{ml}$ of permanganate solution, with shaking on a reciprocating shaker (120 strokes minute $\left.{ }^{-1}\right)$ for exactly 120 seconds. The permanganate solution contained $0.02 M$ potassium permanganate 
$\left(\mathrm{KMnO}_{4}\right)$ and $0.1 \mathrm{M}$ calcium chloride $\left(\mathrm{CaCl}_{2}\right)$, and was adjusted to approximately $\mathrm{pH}$ 7.2 using $0.1 M$ sodium hydroxide $(\mathrm{NaOH})$. After shaking the soil permanganate slurry was allowed to settle for 10 minutes, then $1 \mathrm{ml}$ of the upper supernatant was transferred into a $50 \mathrm{ml}$ centrifuge tube and mixed with $49 \mathrm{ml}$ deionized water. This diluted supernatant was read on a DU720 spectrophotometer, and the reduction of permanganate was quantified as the decline compared to a no-soil control in light absorbance at $550 \mathrm{~nm}$. The change in the concentration of $\mathrm{KMnO}_{4}$ was used to estimate the amount of oxidized C. Sample POXC was calculated as in Weil et al. (2003) as follows:

$\operatorname{POXC}\left(\mathrm{mg} \mathrm{kg}^{-1}\right)=\left[0.02 \mathrm{molL}^{-1}-(\mathrm{a}+\mathrm{bz})\right] \times\left(9000 \mathrm{mg} \mathrm{Cmol}^{-1}\right) \times\left(\frac{0.02 \mathrm{~L} \mathrm{solution}}{0.0025 \mathrm{~kg} \text { soil }}\right)$

where $0.02 \mathrm{~mol} \mathrm{~L}^{-1}$ is the initial concentration of the $\mathrm{KMnO}_{4}$ reactant, a and $\mathrm{b}$ are the intercept and slope of the standard curve, respectively, $\mathrm{z}$ is the sample absorbance, $9000 \mathrm{mg} \mathrm{C} \mathrm{mol}^{-1}$ is the amount of $\mathrm{C}(0.75 \mathrm{~mol})$ oxidized by $1 \mathrm{~mol}$ of $\mathrm{MnO}_{4}$, changing $\mathrm{Mn}^{7+}$ to $\mathrm{Mn}^{4+}$, and $0.0025 \mathrm{~kg}$ soil is the amount of soil reacted with $\mathrm{KMnO}_{4}$.

\subsection{Statistical Analyses}

The experiments at both sites used a randomized complete block split-split-plot design with four replications, where the two pre-cover crop corn side-dressed $\mathrm{N}$ levels (yes or no) comprised the sub-plots and the four post-cover crop corn side dress levels comprised the sub-sub-plots. The sub-sub plots were incorporated into the analysis only for variables measured after the side-dressing $\mathrm{N}$ was applied in the year following the cover crop treatments. Analysis of variance was calculated by DPS 7.05 statistical software (Ruifeng Information Technology Ltd. Co, Hangzhou, China) for 
$\mathrm{C}$ (TOC, POXC) in a given $15 \mathrm{~cm}$ increment of the soil profile, for the sum of all $\mathrm{C}$ in the sampled $(0-105 \mathrm{~cm})$ profile, for plant dry matter, for plant $\mathrm{C} \& \mathrm{~N}$ concentration. Block effects were treated as random variables, whereas cover crop treatments and $\mathrm{N}$ levels were considered fixed effects. Linear regression analyses were used to examine the relationship between TOC and POXC for samples grouped as surface soil (0-30 $\mathrm{cm})$, shallow subsoil $(30-60 \mathrm{~cm})$ and deep soil $(60-105 \mathrm{~cm})$. Mean comparisons were performed using Fisher's protected least significant difference (LSD) when the ANOVA indicated a statistically significant effect $(P<0.05)$.

\section{Results}

\subsection{Cover Crop Dry Matter, Nitrogen and Carbon Concentrations and C: $N$ ratio}

Forage radish dry matter production ranged from 1965 to more than $3361 \mathrm{~kg} \mathrm{ha}^{-1}$ for shoots and 1532 to more than $3740 \mathrm{~kg} \mathrm{ha}^{-1}$ for the fleshy tap roots (Table 3). Forage values for radish shoot and root dry matter were significantly higher in the high $\mathrm{N}$ than in the low $\mathrm{N}$ subplots for any individual site-year. Weeds dry matter was not collected at BARC 1-18 in winter. Forage radish produced less root dry matter than shoot regardless of $\mathrm{N}$ level and both radish shoot and root dry matter was increased markedly by the high $\mathrm{N}$ level at BARC 1-18 and 1-21. Weeds produce much less shoot dry matter than did the radish and but did respond significantly to $\mathrm{N}$ level at BARC 1-21. Root dry matter was not determined for weeds.

Nitrogen uptake by cover crops is influenced by both the total dry matter accumulation and the tissue $\mathrm{N}$ concentration. Under high $\mathrm{N}$ level, $\mathrm{N}$ uptake by radish shoots at BARC1-21 was significantly greater than under low $\mathrm{N}$ level $(110.7 \mathrm{~kg} \mathrm{~N}$ 
ha $^{-1}$ compared with $59.5 \mathrm{~kg} \mathrm{~N} \mathrm{ha}^{-1}$ ) (Table 3). The amounts of $\mathrm{N}$ and $\mathrm{C}$ captured in the radish shoots at BARC1-21 were nearly 4 times greater than in weeds under both $\mathrm{N}$ levels (Table 3). The forage radish roots had a significantly greater average $\mathrm{C}: \mathrm{N}$ ratio than the shoots (23 versus 15$)$. The $\mathrm{C}: \mathrm{N}$ ratio was lower in forage radish shoots than in winter weeds in the high $\mathrm{N}$ plots.

In BARC 1-18, the whole plant (shoot + fleshy root) $\mathrm{N}$ uptake by radish was 154 kg $\mathrm{N} \mathrm{ha}^{-1}$ in the high $\mathrm{N}$ subplots compared to $77 \mathrm{~kg} \mathrm{~N} \mathrm{ha}^{-1}$ in the low $\mathrm{N}$ subplots. In BARC 1-21, the whole plant (shoot + fleshy root) $\mathrm{N}$ uptake by radish was $145 \mathrm{~kg} \mathrm{~N}$ $\mathrm{ha}^{-1}$ in the high $\mathrm{N}$ subplots compared to $80 \mathrm{~kg} \mathrm{~N} \mathrm{ha}^{-1}$ in the low $\mathrm{N}$ subplots.

\subsection{Soil C: $N$ ratio}

The soil $\mathrm{C}$ : $\mathrm{N}$ ratio in surface soil $(0-15 \mathrm{~cm})$ ranged from 10:1 to $12: 1$ in RAD plots and from 11:1 to 12:1 in NC plot at both sites (Fig. 4). There was no apparent overall trend in $\mathrm{C}: \mathrm{N}$ ratio with depth, but there was a significant effect of fall cover crop treatment at several depths in the subsoil. At the $60-75 \mathrm{~cm}$ depth the $\mathrm{C}: \mathrm{N}$ ratio was significantly higher in the NC than in the RAD plots. In contrast, at the $90-105 \mathrm{~cm}$ depth the C:N ratio was significantly higher in the RAD than in the NC plots. These effects were consistent across both sites and $\mathrm{N}$ treatments (Fig. 4).

\subsection{Soil organic carbon and permanganate oxidizable carbon}

The depth distribution of TOC was similar at each site (BARC1-18 and 1-21) for different seasons (Feb 2012 and May 2013), and was not significantly impacted by cover treatment (Fig. 5 and Fig. 6). A non-linear decrease in TOC occurred (Fig. 7) from the 0-15 to 90-105 cm depth intervals for high and low $\mathrm{N}$ conditions, from an 
average high of $11.0 \mathrm{~g} \mathrm{~kg}^{-1}$ at $0-15 \mathrm{~cm}$ to $1.6 \mathrm{~g} \mathrm{~kg}^{-1}$ at $60-105 \mathrm{~cm}$ at BARC1-18 (Fig. 5). At BARC1-21, TOC decreased from $11.82 \mathrm{~g} \mathrm{~kg}^{-1}$ in the uppermost layer to $2.0 \mathrm{~g}$ $\mathrm{kg}^{-1}$ below $60 \mathrm{~cm}$ (Fig. 6). While there was no significant difference in TOC between radish (RAD) and no cover crop (NC) treatments for each depth interval at each site, the TOC in RAD was higher (10.3 $\mathrm{g} \mathrm{C} / \mathrm{kg})$ compared with $\mathrm{NC}(9.3 \mathrm{~g} \mathrm{C} / \mathrm{kg})$ in surface soil depth $(0-30 \mathrm{~cm})$ when analyzed across both site years.

The POXC levels declined dramatically from the 0-15 to the $15-30 \mathrm{~cm}$ layers, and below. However, the decline with depth for POXC at both sites was more variable than that for TOC and did not fit well to a similar non-linear equation (Fig. 8). Forage radish impacts on POXC were observed both in the surface soil layer as well as in subsoil layers, under both high and low $\mathrm{N}$ conditions (Fig. 5 and Fig. 6). POXC increased more in cover treatment than no cover with soil depth increase, especially in deeper soil. The RAD cover crop treatment significantly increased POXC in the 0-15 cm layer averaged across high and low $\mathrm{N}$ conditions $\left(649 \mathrm{mg} \mathrm{kg}^{-1}\right.$ compared with 624 $\mathrm{mg} \mathrm{kg}^{-1}$ at BARC 1-18; $569 \mathrm{mg} \mathrm{kg}^{-1}$ compared with $492 \mathrm{mg} \mathrm{kg}^{-1}$ at BARC 1-21) (Fig. 5 and Fig. 6). In addition, POXC also was significantly higher following RAD than $\mathrm{NC}$ at $90-105 \mathrm{~cm}$ (431 mg kg-1 compared with $295 \mathrm{mg} \mathrm{kg}^{-1}$ at BARC 1-18; $143 \mathrm{mg}$ $\mathrm{kg}^{-1}$ compared with $123 \mathrm{mg} \mathrm{kg}^{-1}$ at BARC 1-21). Overall, $\mathrm{N}$ fertilizer significantly increased POXC levels for both surface and deep soil layers in 2012 and 2013 $(P<0.05)$ (Fig. 5 and Fig. 6). When all the nitrogen fertilized plots from both site years are considered, soil POXC in 0-30 $\mathrm{cm}$ was significantly greater following radish (535.7 $\mathrm{mg}$ POXC/kg) than following no cover crop (418.2 $\mathrm{mg}$ POXC/kg). 
The proportion of TOC present as POXC generally increased with soil depth. The $\mathrm{POXC} / \mathrm{TOC}$ ratio was not influenced by cover treatments in the $0-45 \mathrm{~cm}$ soil layer (Fig.5 and Fig. 6). However, after RAD at both sites, the soil TOC generally had a higher of POXC at depths from 75 to $105 \mathrm{~cm}$ for both high and low $\mathrm{N}$ conditions.

Soil POXC decreased dramatically with soil depth below A horizon in June and August 2012. Where N fertilizer was applied (all plots except N0, June 2012), soil POXC was significantly greater following radish than following no cover crop (0-30 cm) (Fig. 9). At 0-15 cm, POXC was 5, 33, and 30\% higher for RAD than NC in June for $\mathrm{N} 0, \mathrm{~N} 100$, and N150, respectively. At $0-30 \mathrm{~cm}, \mathrm{POXC}$ in RAD soils was $23 \%$ higher in N50, $20 \%$ in N100, and 26\% in N150 compared with that in NC soils in August. Meanwhile, soil POXC exhibited a logarithmic decrease with depth for all treatments in August, although RAD showed a more pronounced decrease than NC. Forage radish impacts on POXC were observed not only for surface soils, but for subsurface soils in June 2012. The RAD soils in N0 in the 45 to $60 \mathrm{~cm}$ and 60 to 75 $\mathrm{cm}$ depth both had 37\% higher POXC, and 32\% higher in $\mathrm{N} 150$ in the 30 to $45 \mathrm{~cm}$ in June compared with NC. On the contrary, the NC soils in N50 in the 30 to $60 \mathrm{~cm}$ had $13 \%$ higher POXC, and 37\% higher in N100 in the 60 to $75 \mathrm{~cm}$ in June compared with RAD.

Soil POXC from all sampling points and soil depth intervals at two fields (BARC1-18 and 1-21), were regressed with their total organic C contents and were found to be highly correlated overall, but not for 30-60 cm (Fig. 10). However, for POXC in deep soil $(60-105 \mathrm{~cm})$, the slope of the regression against TOC (POXC 
/TOC ratio $=0.22)$ was much steeper than for the surface soil $(0-30 \mathrm{~cm})$ with POXC /

TOC ratio $=0.05$.

\section{Discussion}

\subsection{Cover Crop Dry Matter, Nitrogen and Carbon Concentrations and $C: N$ ratio}

Forage radishes were highly variable in dry matter partitioning, with the fleshy root accounting for 36 to $55 \%$ of total plant dry matter. Dean and Weil (2009) reported similar variability in root/shoot ratio and ascribed this in part to the highly variable size of the fleshy taproot of the radishes, often inversely related to localized plant density. Forage radish displayed the potential to take up large quantities of soil $\mathrm{N}$ in fall following silage corn. The $\mathrm{N}$ uptake capabilities were especially apparent in the N-rich soil environment (Table 3). Thorup-Kristensen (1993) also reported that $\mathrm{N}$ uptake by cover crops increased with increasing amounts of soil mineral N. For the two fields (BARC1-18 and 1-21) sampled in Dec. 2011 and 2012, the forage radishes roots contained on average, $36 \sim 55 \%$ of the total $\mathrm{C}$ and $23 \sim 50 \%$ of the total $\mathrm{N}$ with the remainder in the above ground biomass (Table 3). This result is also consistent with the data reported for similar conditions in New York State, where $45 \sim 57 \%$ of total C and $29 \sim 52 \%$ of total $\mathrm{N}$ were present in the roots (Ketterings et al., 2011).

The 63 to $80 \mathrm{~kg} \mathrm{~N} \mathrm{ha}^{-1}$ increase (143-80 to 157-77) in $\mathrm{N}$ uptake by radish plant growing in the subplots that had received $\mathrm{N}$ side-dress solution in the previous June (Table 3), suggests that a large proportion of the $112 \mathrm{~kg} \mathrm{~N} \mathrm{ha}^{-1}$ applied as a side-dressing to the corn in June was not used by the corn crop and remained within the root zone of the radish during the fall in both years of the study. By contrast, the 
weeds in the no cover plots did not respond significantly to the residual side-dressed $\mathrm{N}$, suggesting the $\mathrm{N}$ was deeper than the weed root systems could reach in fall.

The C:N ratio of forage radishes in the two sites (19:1-27:1 for roots and 11:1-17:1 for shoots) was consistent with the findings (22:1-32:1 for roots and 12:1-16:1 for shoots as reported in Ketterings et al., 2011).

\subsection{Soil $\mathrm{C}: \mathrm{N}$ ratio}

The C:N ratio in the organic matter of arable (Ap) horizons commonly ranges from 8:1 to 15:1 (Weil and Brady, 2016), this is in accordance with our results (Fig. 4). The soil $\mathrm{C}: \mathrm{N}$ ratio at subsoil depth $(60-75 \mathrm{~cm})$ in $\mathrm{NC}$ was significantly higher than in RAD at both sites (Fig. 4). This may be associated with the high clay content in the argillic (Bt) horizon at this depth in combination with decomposed radish root materials in the RAD plots. Higher clay content is often associated with more decomposed organic matter with lower C:N ratio (Diekow et al., 2005 a; Ouédraogo et al., 2006; Yamashita et al., 2006). The C:N ratio in RAD tended to decline while increase in NC with depth $(45-75 \mathrm{~cm})$ at both sites (Fig. 4). Diekow et al. (2005 b) found that soil $\mathrm{C}: \mathrm{N}$ ratio declined by depth between 47.5 and $107.5 \mathrm{~cm}$ along with an increase in clay content. However, they observed an opposite trend between 7.5 and $47.5 \mathrm{~cm}$ depths. Sá et al (2001) also reported that a trend of increased soil C:N ratio with depth. This may be attributed to some high C:N soluble organic compounds (e.g., organic acids) leaching into deeper layers (Diekow et al., 2005). It remains unclear why the use of a fall RAD cover crop either increased the total $\mathrm{N}$ or reduced the total $\mathrm{C}$ to result in a significantly lower $\mathrm{C} / \mathrm{N}$ ratio in the $\mathrm{Bt}$ horizon. 


\subsection{Soil organic carbon and permanganate oxidizable carbon}

Although forage radish is an increasingly popular cover crop in both Europe (Allison et al. 1998; Kristensen and Thorup-Kristensen 2004) and North America (Bryant et al., 2013), very little, if any, work has been carried out on its effects on carbon distribution in profile. The TOC decline with soil depth in this study is typical of arable soils and reflects decreased root density with depth (Mutegi et al., 2011). This pattern of decreased root density with depth is thought to be associated with a parallel decline in rhizodeposition with depth (Petersen et al., 2005). Mutegi et al (2013) also reported that ${ }^{14} \mathrm{C}$ mainly concentrated across the $0-45 \mathrm{~cm}$ soil depth for different tillage treatments after forage radish biomass incorporation. While there were no significant differences in TOC between RAD and NC for any depth interval at either site, the TOC in RAD tended $(P<0.05)$ to be higher compared with NC in surface soil depth $(0-30 \mathrm{~cm})$ (Fig. 5 and Fig. 6). High above- and below-ground biomass forage radish yields 2-4 $\mathrm{t} \mathrm{ha}^{-1}$ (Kristensen and Thorup-Kristensen, 2004) could significantly boost soil carbon input, thus reducing the potential depletion of soil carbon resulting from a prolonged fallow period from late summer to late spring.

Forage radish impacts on active carbon (POXC) were observed to be significant in both surface soil and, subsoil layers (Fig. 5 and Fig. 6). As a low C:N ratio of forage radish biomass (Table 3), high and fast initial mineralization occurred (Mafongoya et al., 1998). This high and fast initial mineralization is the result of a fast turnover of the most easily decomposable components of radish material, such as free amino acids, amino sugars, carbohydrates and other cell constituents (Watkins and 
Barraclough, 1996; Mutegi et al., 2013). On the basis of the seven-pool SOM model $(\mathrm{CN}-\mathrm{SIM})$ results, researchers estimated that about $8-10 \%$ of original forage radish $\mathrm{C}$ remained in the soil for up to $30 \mathrm{yr}$ after biomass incorporation (Mutegi et al., 2013). Combining these CN-SIM model forecast results with Jenkinson and Rayner (1977) findings, Mutegi et al (2013) estimate that over a 30-yr period of continuous autumn forage radish establishment as cover crop, at least $4.9 \mathrm{t} \mathrm{C} \mathrm{ha}^{-1}$ forage radish $\mathrm{C}$ with a residence time of more than $20 \mathrm{yr}$ in the soil could be stored in the soil.

Weil et al. (2003) stated that compared to TOC, POXC measured by their method estimates a C pool more closely associated with soil biological functions. In this study, the POXC was significantly higher in the high $\mathrm{N}$ soil at several depths, especially in the lower subsoil, suggesting that the more N-rich soil stimulated more root growth and rhizodeposition by both the corn crop that was fertilized and following radish cover crop.

A strong positive relationship between POXC and SOC has been widely reported previously (Weil et al., 2003; Wuest et al., 2006; Jokela et al., 2009; Culman et al., 2012). The SOC is determined by complete oxidation of all soil C, while POXC relies on partial oxidation of the only the more easily oxidized $\mathrm{C}$ pool. Thus Culman et al. (2012) suggests that POXC can also serve as a rapid and field-adaptable method to estimate TOC.

In our study, TOC and POXC were significantly related at both experiment sites (Fig. 10). However, the overall correlation between the two carbon measures was not as close as in other studies where all samples came from the surface soil. In fact, our 
data suggest that the relationship between TOC and POXC may be different in subsoil than in surface soils. The significantly higher ratio of POXC/TOC in the subsoil layers could be due to recent root exudates and rhizodeposition making up a larger fraction of the much small total amount of organic matter present in the subsoil. Also, with higher microbial populations and respiration activity nearer the soil surface, compounds comprising POXC may be mineralization more quickly than in deeper soil layer, thus causing POXC in surface soil to be more rapidly oxidized or converted into more protected TOC than in the deeper soil in this experiment.

\section{Conclusions}

There has been very little, if any, previous investigations about the carbon distribution in profile and sequestration potential of autumn-winter established forage radish. Our data indicate that forage radish impacted soil carbon quantities and distribution in surface and deep depth compared with fallow treatments, especially for POXC. Additionally, a strong positive relationship between POXC and SOC has also been displayed in this study. We concluded that although forage radish is grown for a short period, and at a time characterized by low temperature (autumn-winter), forage radish cover crops contribute a substantial amount of $\mathrm{C}$ during growth and after biomass decomposed. Forage radish has a potential for mitigating against soil $\mathrm{C}$ depletion through enhancement of soil organic matter.

\section{Acknowledgements}

This study was partially funded by the USDA Sustainable Agriculture Research and Education program. We thank Kevin Conover (Univ. of Maryland) for help in taking 
deep soil cores, Mujen Wang for assistance with field and lab work, the editor and reviewers for constructive feedback. 


\section{References}

Allison, M.F., Armstrong, M.J., Jaggard, K.W., Todd, A., 1998. Integration of nitrate cover crops into sugar beet (Beta vulgaris) rotations. I. Management and effectiveness of nitrate cover crops. J. Agr. Sci. 130, 53-60.

Awale, R., Chatterjee A., Franzen, D., 2013. Tillage and N-fertilizer influences on selected organic carbon fractions in a north dakota silty clay soil. Soil Till. Res. $134,213-222$.

Baker, J.M., Ochsner, T.E., Venterea, R.T., Griffis, T.J., 2007. Tillage and soil carbon sequestration—what do we really know? Agr. Ecosyst. Environ. 118, 1-5.

Bryant, L., Stockwell, R., White, T., 2013. Counting cover crops National Wildlife Federation,

Washington,

D.C. http://www.nwf.org/ /media/PDFs/Media\%20Center\%20-\%20Press\%20Releases /10-1-13_CountingCoverCrops-FINALlowres.ashx.

Chen, G.H., Weil R.R., 2010. Penetration of cover crop roots through compacted soils. Plant Soil. 331, 31-43.

Chen, H., Hou, R., Gong, Y., Li, H., Fan, M., Kuzyakov, Y., 2009. Effects of 11 years of conservation tillage on soil organic matter fractions in wheat monoculture in loess plateau of China. Soil Till. Res. 106, 85-94.

Culman, S.W., Snapp, S.S., Freeman, M.A., Schipanski, M.E., Beniston, J., Lal, R., Drinkwater, L.E., Franzluebbers, A.J., Glover, J.D., Grandy, A.S., Lee, J., Six, J., Maul, J.E., Mirsky, S.B., Spargo, J.T., Wander, M.M., 2012. Permanganate oxidizable carbon reflects a processed soil fraction that is sensitive to 
management. Soil Sci. Soc. Am. J. 76, 494-504.

Dean, J.E., Weil, R.R., 2009. Brassica cover crops for $\mathrm{N}$ retention in the Mid-Atlantic coastal plain. J. Environ. Qual. 38, 520-528.

Diekow, J., Mielniczuk, J., Knicker, H., Bayer, C., Dick, D.P, Kogel-Knaber, I., 2005 a. Carbon and nitrogen stocks in physical fractions of a subtropical Acrisol as influenced by long-term no-till cropping systems and N fertilization. Plant Soil. $268,319-328$.

Diekow, J., Mielniczuk, J., Knicker, H., Bayer, C., Dick, D.P., Kögel-Knabner, I., 2005 b. Soil C and N stocks as affected by cropping systems and nitrogen fertilization in a southern Brazil Acrisol managed under no-tillage for 17 years. Soil Till. Res. 81, 87-95.

DuPont, S.T., Culman, S.W., Ferris, H., Buckley, D.H., Glover., J.D., 2010. No-tillage conversion of harvested perennial grassland to annual cropland reduces root biomass, decreases active carbon stocks, and impacts soil biota. Agr. Ecosyst. Environ. 137, 25-32.

Gunapala, N., Scow, K.M., 1998. Dynamics of soil microbial biomass and activity in conventional and organic farming systems. Soil Biol. Biochem. 30, 805-816.

Jandl, R., Rodeghiero, M., Martinez, C., Cotrufo, M.F., Bampa, F., Van Wesemael, B., Harrison, R.B., Guerrini, I.A., Richter, D.D. Jr., Rustad, L., Lorenz, K., Chabbi, A., Miglietta, F., 2014. Current status, uncertainty and future needs in soil organic carbon monitoring. Sci. Total. Environ. 468-469, 376-83.

Jenkinson, D.S., Rayner, J.H., 1977. The turnover of soil organic matter in some of 
the Rothamsted classical experiments. Soil Sci. 123, 298-305.

Jokela, W.E., Grabber, J.H., Karlen, D.L., Balser, T.C., Palmquist, D.E., 2009. Cover crop and liquid manure effects on soil quality indicators in a corn silage system. Agron. J. 101, 727-737.

Ketterings, Q.M., Kingston, J., Mcivennie, S., Long, E., Godwin, G., Gami, S., Stanyard, M., Czymmek, K., 2011. Cover crop carbon and nitrogen content, fall 2011 sampling. What's Cropping Up? 21, 1-4.

Kremen, A., Weil, R.R., 2006. Monitoring nitrogen uptake and mineralization by brassica cover crops in Maryland. http://crops.confex.com/crops/wc2006/techprogram/P17525.HTM.

Kristensen, H.L., Thorup-Kristensen, K., 2004. Root growth and nitrate uptake of three different catch crops in deep soil layers. Soil Sci. Soc. Am. J. 68, 529-537.

Lawley, Y.E., Weil, R.R, Teasdale, J.R., 2011. Forage radish winter cover crops suppress winter annual weeds in fall and before corn planting. Agron. J. 103, $137-144$.

Lucas, S.T., Weil, R.R., 2012. Can a labile carbon test be used to predict crop responses to improved soil organic matter management? Agron. J. 104, $1160-1166$

Mafongoya, P.L., Nair, P.K.R, Dzowela, B.H., 1998. Mineralization of nitrogen from decomposing leaves of multipurpose trees as affected by their chemical composition. Biol. Fert. Soils. 27, 143-148.

Melero, S., López-Garrido, R., Murillo, J.M., Moreno, F., 2009. Conservation tillage, 
short and long - term effects on soil carbon fractions and enzymatic activities under Mediterranean conditions. Soil Till. Res. 104, 292-298.

Miles, R.J., Brown, J.R., 2011. The Sanborn field experiment, implications for long-term soil organic carbon levels. Agron. J. 103, 268-278.

Morrow, J.G., Huggins, D.R., Carpenter-Boggs, L.A., Reganold, J.P., 2016. Evaluating measures to assess soil health in long-term agroecosystem trials. Soil Sci. Soc. Am. J. (Publish online).

Mutegi, J.K., Petersen, B.M., Munkholm, L.J., 2013. Carbon turnover and sequestration potential of fodder radish cover crop. Soil Use Manage. 29, $191-198$.

Mutegi, J.K., Petersen, B.M., Munkholm, L.J., Hansen, E.M., 2011. Belowground carbon input and translocation potential of fodder radish cover-crop. Plant Soil. $344,159-175$.

Ouédraogo, E., Mando, A., Brussaard, L., 2006. Soil macrofauna affect crop nitrogen and water use efficiencies in semi-arid West Africa. Eur. J. Soil Biol. 42, $275-277$.

Petersen, B.M., Berntsen, J., Hansen, S., Jensen, L.S., 2005. CN-SIM-a model for the turnover of soil organic matter. I. Long term carbon and radiocarbon development. Soil Biol. Biochem. 37, 359-374.

Plaza-Bonilla, D., Álvaro-Fuentes, J. Cantero-Martínez, C., 2014. Identifying soil organic carbon fractions sensitive to agricultural management practices. Soil Till. Res. 139, 19-22. 
Sa', J.C.D.M., Cerri, C.C., Dick, W.A., Lal, R., Vesnke-Filho, S.P., Piccolo, M.C., Feigl, B.E., 2001. Organic matter dynamics and carbon sequestration rates for a tillage chronosequence in a Brazilian Oxisol. Soil Sci. Soc. Am. J. 65, $1486-1499$.

Spargo, J.T., Cavigelli, M.A., Mirsky, S.B., Maul, J.E., Meisinger, J.J., 2011. Mineralizable soil nitrogen and labile soil organic matter in diverse long-term cropping systems. Nutr. Cycl. Agroecosys. 90, 253-266.

Thorup-Kristensen, K., 1993. The effect of nitrogen catch crops on the nitrogen nutrition of a succeeding crop, I. Effects through mineralization and pre-emptive competition. Acta Agric. Scand. Section B. 43, 74-81.

Tisdall, J.M., Oades, J.M., 1982. Organic matter and water-stable aggregates in soils. J. Soil Sci. 33, 141-163.

Veum, K., Goyne, K., Kremer, R., Miles, R., Sudduth, K., 2014. Biological indicators of soil quality and soil organic matter characteristics in an agricultural management continuum. Biogeochemistry. 117, 81-99.

Watkins, N., Barraclough, D., 1996. Gross rates of N mineralization associated with the decomposition of plant residues. Soil Biol. Biochem. 28, 169-175.

Weil, R.R., Brady, N.C., 2016. The Nature and Properties of Soils, 15th ed. Pearson Education, New York.

Weil, R.R., Islam, K.R, Melissa, M.A, Joel, B.G, Samson-Liebig, S.E., 2003. Estimating active carbon for soil quality assessment, A simplified method for laboratory and field use. Am. J. Altern. Agric. 18, 3-17. 
Weil, R.R., Magdoff, F., 2004. Significance of soil organic matter to soil quality and health, in: Magdoff, F., Weil, R.R. (Eds.), Soil organic matter in sustainable agriculture. CRC Press, Boca Raton, Florida, pp, 1-43.

White, C.M., Weil, R.R., 2011. Forage radish cover crops increase soil test Phosphorus surrounding holes created by radish taproots. Soil Sci. Soc. Am. J. 75, $121-130$.

Wuest, S.B., Williams, J.D., Gollany, H.T., 2006. Tillage and perennial grass effects on ponded in filtration for seven semi-arid loess soils. J. Soil Water Conserv. 61, $218-223$.

Yamashita, T., Flessa, H., John, B., Helfrich, M., Ludwig, B., 2006. Organic matter in density fractions of water-stable aggregates in silty soils: Effect of land use. Soil Biol. Biochem. 38, 3222-3234. 


\section{Table 1}

Soil characteristics of the tested soils in 0-20 cm depth

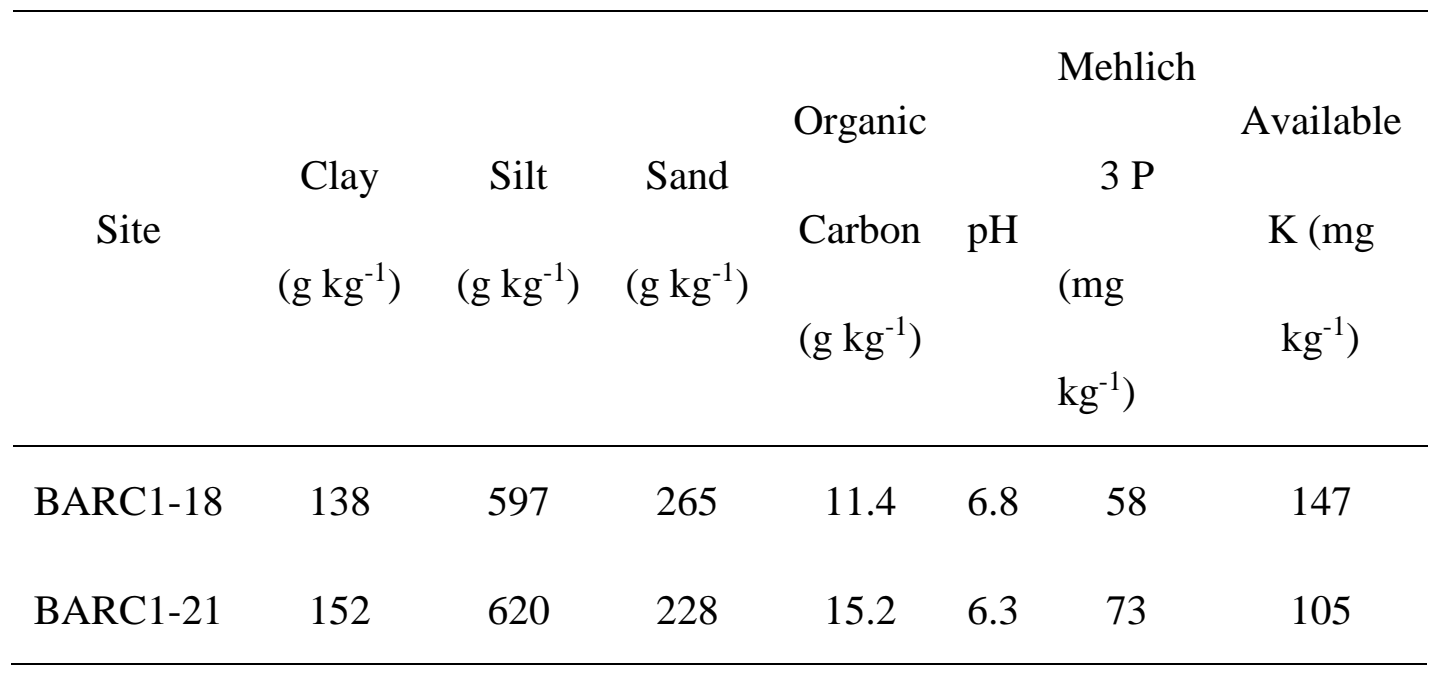

Table 2

Management history at two research sites

\begin{tabular}{|c|c|c|c|c|}
\hline Site & Years & Main Crop & Cover Crop & $\begin{array}{c}\text { Dairy Manure } \\
\text { Slurry }\end{array}$ \\
\hline \multirow[t]{8}{*}{$1-18$} & 2008 & Soybean (Glycine & Cereal Rye (Secale cereal L.) & None \\
\hline & & $\max \mathrm{L})$. & & \\
\hline & 2009 & Silage Corn $(\mathrm{Zea}$ & None & $47000 \mathrm{~L} \mathrm{ha}^{-1}$ \\
\hline & & mays L.) & & \\
\hline & 2010 & Soybean & Cereal Rye & None \\
\hline & 2011 & Silage corn & Forage Radish & $47000 \mathrm{~L} \mathrm{ha}^{-1}$ \\
\hline & 2012 & Silage corn & Triticale (Tritico secale & None \\
\hline & & & Wittmack L.) & \\
\hline $1-21$ & 2008 & Silage Corn & Barley (Hordeum vulgare L.) & $47000 \mathrm{~L} \mathrm{ha}^{-1}$ \\
\hline
\end{tabular}




\begin{tabular}{|c|c|c|c|}
\hline 2009 & Soybean & None & None \\
\hline 2010 & Silage corn & Wheat (Triticum aestivum L.) & None \\
\hline 2011 & Soybean & Wheat cover & None \\
\hline 2012 & Corn Silage & Forage Radish & $47000 \mathrm{~L} \mathrm{ha}^{-1}$ \\
\hline 13 & Corn Silage & & \\
\hline
\end{tabular}

\section{Table 3}

Cover crop dry matter production, $\mathrm{N}$ concentration, $\mathrm{C}$ concentration and $\mathrm{C}: \mathrm{N}$ ratio measured for forage radish and weeds in winter at USDA Dairy Farm of Beltsville Agriculture Research Center, Beltsville, Maryland (BARC1-18 and 1-21) experimental sites during 2 yr. Forage radish and weeds biomass were sampled in the early winter and root samples were of the main portion of the radish taproot. High $\mathrm{N}$ and Low N represent side-dressed row and non- side-dressed row separately.

\begin{tabular}{|c|c|c|c|c|c|c|c|c|c|}
\hline \multirow{3}{*}{ Items } & \multirow{3}{*}{$\begin{array}{l}\text { Cover } \\
\text { Crop }\end{array}$} & \multicolumn{4}{|c|}{ BARC 1-18 (2011.12) } & \multicolumn{4}{|c|}{ BARC 1-21 (2012.12) } \\
\hline & & \multicolumn{2}{|c|}{ Shoot } & \multicolumn{2}{|c|}{ Root } & \multicolumn{2}{|c|}{ Shoot } & \multicolumn{2}{|c|}{ Root } \\
\hline & & High N & Low N & High N & Low N & High N & Low $\mathrm{N}$ & $\begin{array}{c}\text { High } \\
\text { N }\end{array}$ & Low $\mathrm{N}$ \\
\hline \multirow{2}{*}{$\begin{array}{l}\text { Dry matter, } \\
\mathrm{kg} \mathrm{ha}^{-1}\end{array}$} & $\begin{array}{l}\text { Forage } \\
\text { radish }\end{array}$ & $3031 \mathrm{a} \dagger$ & $1965 b$ & $3748 \mathrm{a}$ & $2172 b$ & $3361 \mathrm{a}$ & $2696 b$ & $1853 a$ & $1532 b$ \\
\hline & Weeds & - & - & - & - & $1056 \mathrm{c}$ & $655 d$ & - & - \\
\hline \multirow{2}{*}{$\begin{array}{l}\text { N content, } \\
\mathrm{kg} \mathrm{ha}^{-1}\end{array}$} & $\begin{array}{l}\text { Forage } \\
\text { radish }\end{array}$ & $78.5 \mathrm{a}$ & $43.0 \mathrm{~b}$ & $75.3 \mathrm{a}$ & $34.0 \mathrm{~b}$ & $110.7 \mathrm{a}$ & $59.5 b$ & $34.1 \mathrm{a}$ & $20.5 b$ \\
\hline & Weeds & - & - & - & - & $28.7 \mathrm{c}$ & $16.9 \mathrm{c}$ & - & - \\
\hline \multirow{2}{*}{$\begin{array}{l}\text { C content, } \\
\mathrm{kg} \mathrm{ha}^{-1}\end{array}$} & $\begin{array}{l}\text { Forage } \\
\text { radish }\end{array}$ & $1164.9 \mathrm{a}$ & $734.8 b$ & $1452.0 \mathrm{a}$ & $845.0 \mathrm{~b}$ & $1194.0 \mathrm{a}$ & $948.4 \mathrm{a}$ & $676.0 \mathrm{a}$ & $558.8 b$ \\
\hline & Weeds & - & - & - & - & $373.8 b$ & $218.6 b$ & - & - \\
\hline \multirow[t]{2}{*}{$\mathrm{C}: \mathrm{N}$ ratio } & $\begin{array}{l}\text { Forage } \\
\text { radish }\end{array}$ & $15.1 b$ & $17.3 \mathrm{a}$ & $20.1 \mathrm{a}$ & $25.1 \mathrm{a}$ & $11.0 \mathrm{~b}$ & $15.9 \mathrm{a}$ & $20.4 b$ & $27.6 a$ \\
\hline & Weeds & - & - & - & - & $13.1 \mathrm{~b}$ & $12.7 \mathrm{~b}$ & - & - \\
\hline
\end{tabular}

$\dagger$ Lowercase letters indicate significantly different means for each site and year $(P<0.05)$. 


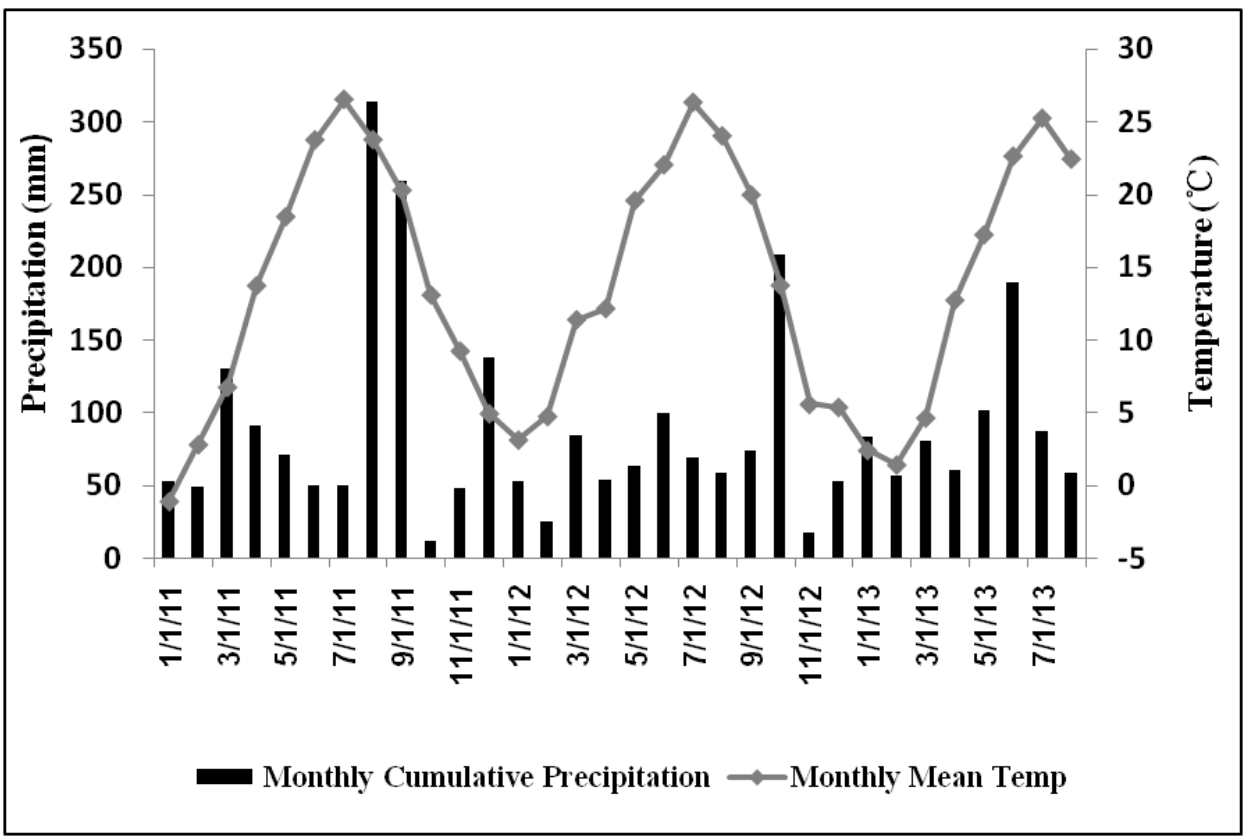

Fig.1. 


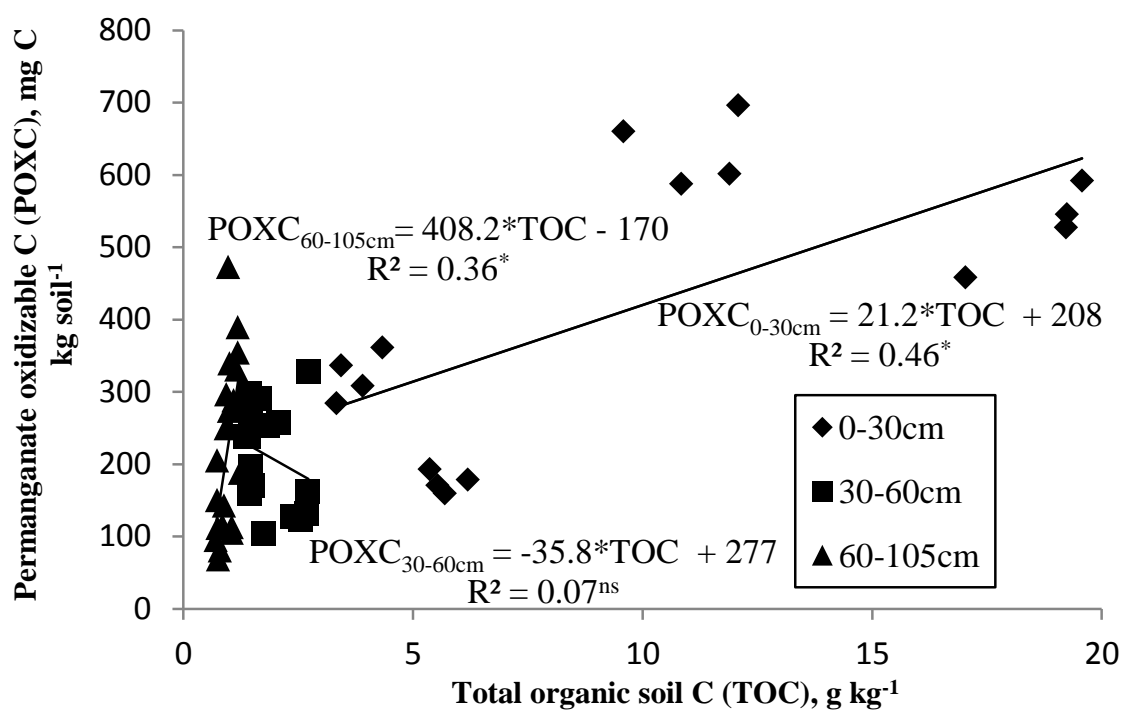

Fig.10 